\title{
What Are Teachers Really Paid? Adjusting Wages for Regional Differences in Cost of Living
}

\section{Charles S. Gascon, Regional Economist}

Qiuhan Sun, Research Associate

trikes by teachers in West Virginia, Oklahoma, Kentucky, Arizona, and Colorado have highlighted differences in teachers' wages across the country. ${ }^{1}$ Teachers in these states have lower-than-average annual wages but also lower-than-average cost of living (COL). Adjusting for differences in COL narrows the differences in teachers' wages across the country, but substantial differences remain. Wages that are adjusted for price-level differences are called "real wages" because they measure the real purchasing power of wages.

Figure 1 shows the relationship between average teachers' wages in 2017 and COL in 2016 measured by regional price parities (RPPs). An RPP of 100 indicates a COL equal to the national average, while an RPP of 110 indicates a COL 10 percent above the national average. States where teachers earn higher wages also happen to be the states with higher COL. Teachers in New York earn the highest nominal wage at $\$ 80,625$ per year, almost twice as much as teachers in Oklahoma, who make the lowest nominal wage at $\$ 41,145$ per year. ${ }^{2}$ However, COL in New York is 15 percent above the national average, while COL in Oklahoma is 10 percent below the national average.

Cost of living explains only some of the differences in teacher pay.

Figure 2 adjusts wages for regional differences in COL. As expected, interstate wage gaps shrink after adjusting for COL, but the differences in wages fail to completely capture the differences in COL. The gap between New York and Oklahoma still exists but significantly shrinks from $\$ 40,000$ to $\$ 28,000$ in real (COL-adjusted) dollars.

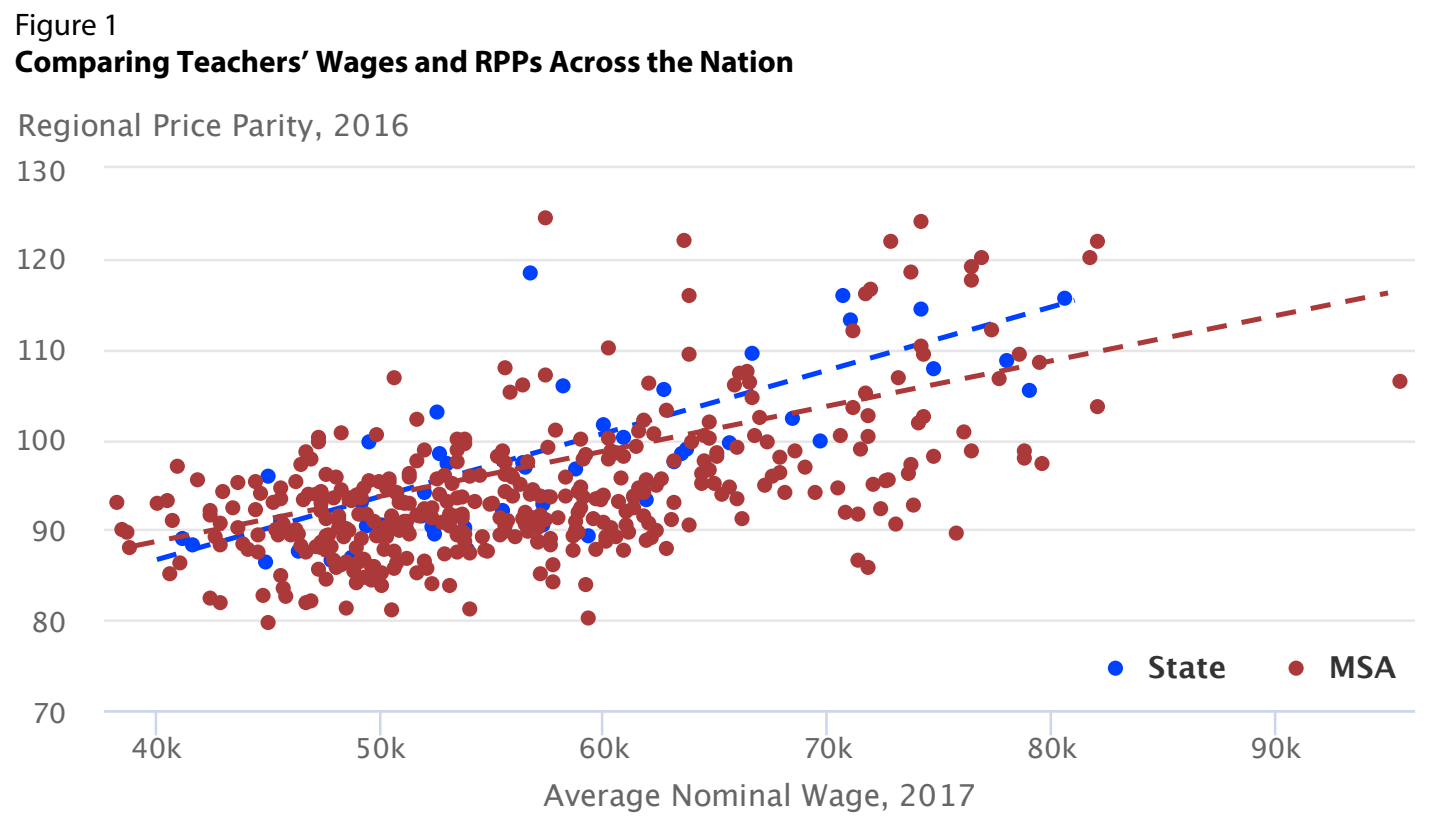

NOTE: A metropolitan statistical area (MSA) is a geographical region with a relatively high population density at its core and close economic ties throughout the area. The dashed line is the fitted linear relation. SOURCE: Bureau of Labor Statistics and Bureau of Economic Analysis. 
Figure 2

Teachers' Wages Adjusted for State COL

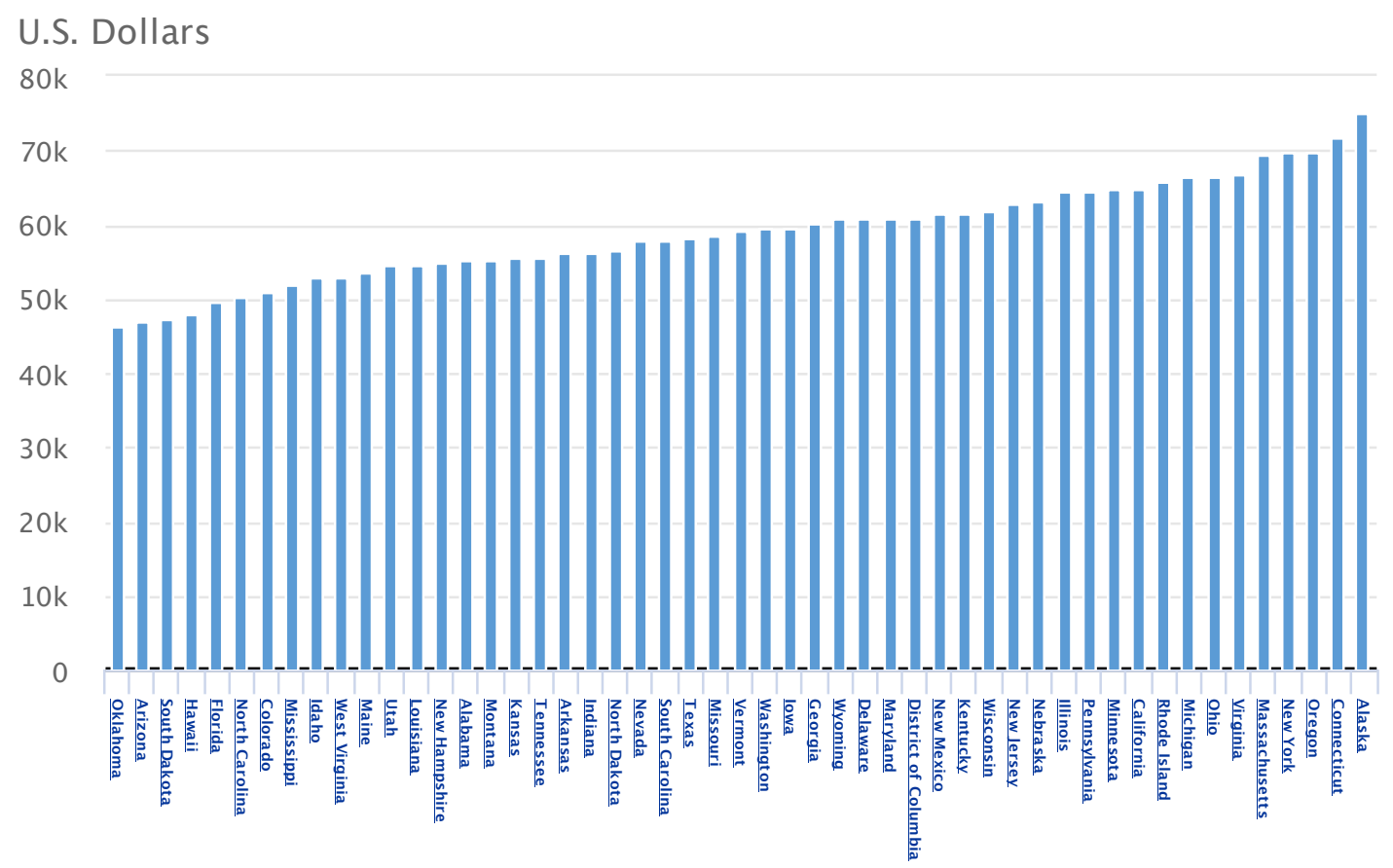

SOURCE: Bureau of Labor Statistics, Bureau of Economic Analysis, and authors' calculations.

\section{Why Should Wages Be the Same/Different Across the Country?}

Economic theory suggests that when goods or services are freely traded or workers are mobile, real wages would tend to equalize over time. For example, firms in laborintensive industries would move to low-cost areas in search of cheaper labor, reducing the demand for workers in the high-cost area. Alternatively, if workers are mobile, they would move to the higher-wage areas, increasing the supply of workers.

Conversely, different regions offer different amenities that impact one's quality of life. Amenities include, for example, the climate and recreational offerings, such as the number of restaurants or parks. ${ }^{3}$ In general, real wages are higher in low-amenity places because workers need more income to compensate for the lack of amenities. Likewise, in general, real wages are lower in high-amenity places because the amenities are part of the workers' compensation. This helps to explain why places such as Hawaii, Florida, Arizona, North Carolina, and Colorado, which are all high-sunshine states, tend to have lower real wages for most occupations, including teachers.

\section{Other Factors Specific to Teachers}

Unlike firms in other industries, schools are unable to relocate to hire lower-wage teachers, although continued growth of online education has made this a possibility for teaching older students. While schools cannot move, teachers can relocate. However, there are some barriers to migration. Public-teacher pension plans set vesting periods that require teachers to stay for a certain number of years before becoming eligible for their retirement contributions. ${ }^{4}$ The difficulty in transferring teacher certifications may also limit cross-state mobility of teachers.

Education spending in each state plays an important role in determining teacher wages. In 2016, public elementary and secondary school spending per pupil in New York was $\$ 22,000$, three times more than the $\$ 7,000$ per pupil in Arizona. ${ }^{5}$ There is a strong positive correlation between public funding for education and teachers' wages: A $\$ 1,000$ difference in a state's education spending per pupil is associated with a $\$ 1,162$ wage difference.

The difference in teacher quality is another possible explanation for cross-state wage differences. Higher pay attracts more able graduates into the profession. As the supply of teachers increases, entry into the profession becomes more competitive and the quality of teachers rises. ${ }^{6}$ Also, there is a clear trade-off between student-teacher ratios and teachers' pay: In general, the higher the studentteacher ratio, the higher the pay. ${ }^{7}$ In fact, the ratio is lower in states such as West Virginia and North Dakota and higher in states such as California and Michigan. ${ }^{8}$ 


\section{ECONOMIC Synopses}

Another factor in wage differences could be mismeasurement from comparing annual wages instead of total compensation. Wage is only one part of the compensation package. Teaching usually offers additional benefits such as pensions and health insurance. Some states may provide benefits instead of additional wages.

\section{Notes}

1 Wages include base rates, commissions, COL allowances, deadheading pay, guaranteed pay, hazard pay, incentive pay, longevity pay, over-the-road pay, piece rates, portal-to-portal rates, production bonuses, and tips.

2 Data are from the Bureau of Labor Statistics (2017). Wages are for both public and private school teachers.

3 See Carlino (1986).

${ }^{4}$ See Aldeman (2015).

5 Data are from the Census Bureau (2018).

6 See Dolton and Marcenaro-Guiterrez (2011).

7 See Dolton and Marcenaro-Guiterrez (2011).

8 NEA Research (2016).

\section{References}

Aldeman, C. Hidden Penalties: How States Shortchange Early-Career Teachers. Bellwether Education Partners, 2015.

Bureau of Labor Statistics. "Occupational Employment Statistics." Last modified date: May 2017; https://www.bls.gov/oes/.

Carlino, G.A. "Do Regional Wages Differ?" Business Review, July 1986, pp. 17-25.

Census Bureau. "2016 Annual Survey of School System Finances." Last modified date: May 17, 2018; https://www.census.gov/data/tables/2016/econ/ school-finances/secondary-education-finance.html.

Dolton, P. and Marcenaro-Gutierrez, O.D. "If You Pay Peanuts Do You Get Monkeys? A Cross-Country Analysis of Teacher Pay and Pupil Performance." Economic Policy, 2011, 26(65), pp. 5-55.

NEA Research. "Rankings of the States 2015 and Estimates of School Statistics 2016." National Education Association, May 2016;

http://www.nea.org/home/66703.htm. 